\title{
Russian reformation
}

\author{
Recent reforms of the Russian Academy of Sciences have caused controversy, and the benefits of the \\ changes are debatable. But what is clear is that proper investment in science must become a priority for \\ Russia's government.
}

It has been a stressful summer for Russian scientists. In June 2013, the Russian government announced, out of the blue, a new bill that would imply drastic reforms of the Russian Academy of Sciences. It triggered a rollercoaster of events - as Sergei Stishov explains in his Commentary on page 684 of this issue - that ended three months later when President Vladimir Putin signed the amended, but still highly contentious, bill into law.

The Russian Academy of Sciences is a mammoth institution employing roughly 100,000 people, half of whom are researchers ${ }^{1}$. Although it is often stressed that the Academy's origins can be traced back to Tsar Peter the Great and his 'window on Europe' politics, the present condition of the institution is more the legacy of the Soviet era. The subsequent transformation, after the collapse of the USSR, of the enormous intrinsic potential of the Academy (which comprises almost 500 institutes) into a twenty-first century research organization along the lines of, say, Germany's Max Planck Society, has evidently not been a priority ${ }^{2}$. Indeed, its state of neglect and decay throughout the 1990s caused many scientists to pursue research careers abroad, or to abandon science altogether - and this trend continues today. We see it reflected in the submissions to Nature Physics: many of our Russian authors have foreign affiliations, and only a small fraction of submitted manuscripts comes directly from Russia.

The one major problem that Russian science is suffering from, whichever way you look at it, is money. The wages of Academy-employed scientists are low. Typical basic salaries for researchers at various career stages lie in the range $12,000-24,000$ roubles (€275-550) per month. A PhD-holder gets a monthly bonus of 3,000 roubles ( $€ 70$ ), whereas someone who has earned the degree of Doctor of Sciences - similar to the Habilitation of German academia receives an additional 7,000 roubles $(€ 160)$ per month. (The title of Doctor of Sciences is usually not obtained before the age of forty.) Only the 1,200 or so elected full and corresponding members of the Academy earn near or well above the official average monthly income in Moscow $^{3}$ of 54,000 roubles $(€ 1235)$, with salary additions of $50,000(€ 1150)$ and 25,000 roubles (€575) per month, respectively.

Owing to this poor remuneration situation, applying for research funding has now become an established way of adding to one's income: in many grant applications, a large amount of the requested budget can legally be, and almost invariably is, allocated to boosting the salaries of the applicants. In practice, it means little money is then left for buying equipment, travelling or financing the visits of foreign guest researchers (these are a rarity in Russian laboratories). Consequently, writing grant proposals and producing progress reports are now the order of the day for many Russian researchers, obviously compromising their scientific creativity and productivity. Moreover, scientists sometimes even find themselves having to produce a report before receiving any of the money they have been granted.

A further problem affecting Russian science (and Russian society in general) is that of low pensions. Many scientists on reaching the age of 65 prefer - and who can blame them - to continue working, rather than live on a meagre retirement allowance. About $15 \%$ of the Academy's researchers are older than 70 , and $34 \%$ over 60 years old ${ }^{1}$. As a result, it is difficult for younger scientists to progress and assume higher-responsibility roles such as that of group leader - another reason for talented and motivated graduates to think twice before embarking on a career with the Academy.

It is not all doom and gloom, however. The salaries of scientists employed by universities or the Academy have been increasing, albeit slowly, in recent years. The Russian government is certainly aware of the situation - promises of significant pay rises can be heard occasionally - and it is keen to stop the outpour of bright people from the country. Meanwhile other projects (sponsored in part or completely privately) are gathering momentum.

An example of a promising initiative, driven by scientific enthusiasm and backed by heavy financing, is the Russian Quantum Centre ${ }^{4}$ (RQC), which was founded in December 2010. Located just outside Moscow on the site of the Skolkovo Innovation Centre - Prime Minister Dmitry Medvedev's ambitious high-tech business park, which has provoked both excitement and scepticism ${ }^{5}$ - the RQC is now home to four laboratories dedicated to cutting-edge research in quantum technologies. The current format is that of research units with group leaders who are Russian, but are affiliated with foreign (prestigious) institutes. Scientific results are being published, more groups are planned and recruitment of researchers who will work full-time at the RQC and receive salaries and benefits that are competitive by international standards is continuing.

The RQC is trying hard to become one of the world's leading laboratories for quantum physics. At its second International Conference on Quantum Technologies ${ }^{6}$, held in Moscow in July 2013, participating Academy scientists seemed to embrace the RQC and the project generally met with enthusiasm from delegates (which was not only thanks to the magnificent conference venue, the completely refurbished historic Hotel Ukraina). The event also didn't go unnoticed in the Russian media, as it included a panel discussion for an audience of the general public featuring Russia's (strongly criticized) Education and Science Minister Dmitry Livanov.

It's still early days, but the RQC might very well evolve into a strong model for Russian scientific institutes. Its initial success, however, clearly underlines that whatever the shape of the Academy's reforms, scientific research needs proper funding. For (to paraphrase the Russian romantic poet Mikhail Lermontov) science is like fire - without nourishment, it goes out.

\footnotetext{
References

1. http://ria.ru/infografika/20130705/947888886.html

2. Feigel'man, M. Nature Phys. 3, 138-139 (2007).

3. http://www.gks.ru/free_doc/new_site/population/trud/itog_ monitor/itog-monitor.html

4. http://www.rqc.ru/

5. Butler, D. Nature 500, 262-264 (2013).

6. http://icqt.org/conference/
} 